\title{
Association of Psoriasis with Cushing's Syndrome
}

\author{
Çiğdem TURA BAHADIR, Feyzi GÖKOSMANOĞLU, Elif KILIÇ KAN, Güllçin CENGIZ ECEMIŞ, Ayșegül \\ ATMACA, Hulusi ATMACA, Ramis ÇOLAK \\ Ondokuz Mayıs University School of Medicine \\ Department of Endocrionology and Metabolism \\ Samsun, TURKEY
}

\section{OBJECTIVES}

Psoriasis is a chronic, inflammatory and T-cell mediated autoimmune disease of skin. Its prevalance is 2$3 \%$. It may improve due to immunesupressive effects of hypercortisolemia during the active phase of Cushing's syndrome (CS) and may exacerbate after treatment. The aim of this study was to investigate association of psoriasis with CS.

\section{METHODS}

We prospectively followed 62 patients who had been diagnosed with CS between 2010 and 2014 in our clinic. Of the patients, 60\% was Cushing diease (CD) (29 female, 8 male) and 40\% was ACTHindependent CS (20 female, 5 male). The patients were evaluated for psoriasis.
Table 1: Diagnosis time of psoriasis and features of CS in our patient population

\begin{tabular}{|c|c|c|c|c|c|c|c|}
\hline & $\begin{array}{l}\text { Time of } \\
\text { diagnosis } \\
\text { for psoriasis }\end{array}$ & $\begin{array}{l}\text { Postperative } \\
\text { state of } \\
\text { diease }\end{array}$ & $\begin{array}{l}\text { Tumor } \\
\text { Location }\end{array}$ & $\begin{array}{l}\text { Basal } \\
\text { ACTH } \\
\text { (pg/ml) }\end{array}$ & $\begin{array}{l}\text { Basal } \\
\text { cortisole } \\
\text { ( } \mu g / d \mid)\end{array}$ & $\begin{array}{l}1 \mathrm{mg} \text { DST } \\
(\mu \mathrm{g} / \mathrm{dl})\end{array}$ & Pathology \\
\hline$\overline{1}$ & postoperative & new diagnosis & $\begin{array}{l}\text { adrenal } \\
\text { adenoma }\end{array}$ & $\overline{1}$ & 24 & 26 & $\begin{array}{l}\text { nuclear pleomorphism, } \\
\text { possible malignant } \\
\text { behavior }\end{array}$ \\
\hline 2 & preoperative & exacarbated & $\begin{array}{l}\text { pituitary } \\
\text { adenoma }\end{array}$ & 78 & 19 & 13,6 & $\begin{array}{l}\text { densely granulated } \\
\text { corticotrophic adenoma }\end{array}$ \\
\hline 3 & preoperative & unexacarbated & $\begin{array}{l}\text { pituitary } \\
\text { adenoma }\end{array}$ & 103 & 28 & 11,7 & $\begin{array}{l}\text { densely granulated } \\
\text { corticotrophic adenoma }\end{array}$ \\
\hline
\end{tabular}

ACTH: Adrenocorticotropic hormone DST: Dexamethasone suppression test

\section{RESULTS}

The prevalence of psoriasis was $5 \%$ among our patients with CS. Psoriasis was diagnosed in three patients; two had pituitary adenoma and one had adrenal adenoma. Two were diagnosed before treatment of $\mathrm{CD}$, and the other was diagnosed after two years following remission of ACTH-independent CS. The pathological evaluation of two patients with $\mathrm{CD}$ was reported as densely granulated corticotrophic adenoma and the pathological evaluation of the patient with ACTH-independent CS was reported as adrenocortical adenoma with nuclear pleomorphism and possible malignant behavior. In the light of these findings, potential hypersecretory tumours should be considered. Features of our patients are shown in Table 1.

\section{CONCLUSIONS}

Endogenous hypercortisolism supresses inflammatory response and induces a state of immunesuppression. Once cortisol levels come back to normal following remission of $\mathrm{CS}$, rebound response of immunity may result in exacerbation of autoimmune diseases like psoriasis. Prevalence of psoriasis is elevated in CS. If the patient is known to have a history of stress-responders psoriasis prior to surgery, we should evaluate the patient more carefully and frequently for exacarbation of psoriasis after remission of CS. Autoimmune diseases may exacarbate or may be newly diagnosed because of rebound immunity in remission of CS. 